Журнал«Герспективитаінноваціїнаукиљ

(Серія «Гедагогіка», Серія«Гцихологія», Серія«Медицина»

№2(7) 2022

УДК $371.3+811$

https://doi.org/10.52058/2786-4952-2022-2(7)-68-76

Spirkina Oksana Oleksiivna Candidate of Historical Sciences, Associate Professor, Associate Professor of Foreign Languages Department, Cherkasy Institute of Fire Safety named after Chornobyl Heroes of National University of Civil Defense of Ukraine, Onoprienka St., 8, Cherkasy, 18034, https://orcid.org/0000-0001-7932-0127

Nenko Yuliia Petrivna Doctor of Educational Sciences, Professor, Head of Foreign Languages Department, Cherkasy Institute of Fire Safety named after Chornobyl Heroes of National University of Civil Defense of Ukraine, Cherkasy, 18034, Onoprienka St., 8, https://orcid.org/0000-0001-7868-0155

\title{
TEACHING TO READ TECHNICAL TEXTS IN THE SPECIALTY IN ENGLISH THROUGH A PERSONALITY-ORIENTED APPROACH AS A NECESSARY ELEMENT OF MASTERING A FOREIGN LANGUAGE IN TECHNICAL HIGHER EDUCATIONAL INSTITUTIONS
}

\begin{abstract}
Scientific research is devoted to one of the most significant elements of mastering a foreign language in the technical higher educational institutions teaching reading texts in English in the specialty using a personality-oriented approach.
\end{abstract}

The article focuses on the personality of a student as a higher educational applicant in higher educational institutions of non-linguistic specialties. The importance and necessity of focusing on the needs of applicants for higher education of technical higher educational institutions to master a foreign language through the prism of their future specialty is emphasized.

It is shown that the personality-oriented approach is a methodological orientation of teachers of higher educational institutions, which, based on a system of interrelated concepts, ideas and methods of action, supports and ensures the processes of self-knowledge, self-improvement and self-realization of the personality of a higher educational applicant as a future specialist of the chosen specialty. It is important to realize that the most significant task of higher education in Ukraine is to prepare a professional graduate who is confident in his abilities, capable of critical thinking, innovation and self-education, to set and solve problems.

The connection between the formation of such speech competence as reading and understanding unadapted technical texts in a foreign language and obtaining professional knowledge and skills is emphasized. The higher educational applicant is characterized as a reader of foreign literature in the specialty. The criteria for selecting texts for reading in foreign language classes in technical higher educational institutions are given. Attention is focused on the importance of combining technical texts for studying in foreign language classes into thematic cycles. The necessity of 
observing the sequence and repeatability of lexical material in the above-mentioned thematic cycles is emphasized, since receptive assimilation of lexical units is possible only if they are sufficiently repeatable in texts for reading. It is explained that only systematic reading of foreign language literature in the specialty contributes to the accumulation of the necessary vocabulary. It is studied that thematic, system-related cycles of professionally-oriented technical texts for reading in a foreign language is advisable to accompany dictionaries that include basic concepts and terms, memorizing which can facilitate and speed up the process of learning to read technical literature in the specialty.

Keywords: professionally-oriented technical texts, personality-oriented approach, training in reading technical texts in the specialty, mastering a foreign language, competence.

Спіркіна Оксана Олексіївна кандидат історичних наук, доцент, доцент кафедри іноземних мов, Черкаський інститут пожежної безпеки імені Героїв Чорнобиля Національного університету цивільного захисту України, вул. Онопрієнка, 8, м. Черкаси, 18034, https://orcid.org/0000-0001-7932-0127

Ненько Юлія Петрівна доктор педагогічних наук, професор, завідувач кафедри іноземних мов, Черкаський інститут пожежної безпеки імені Героїв Чорнобиля Національного університету цивільного захисту України, м. Черкаси, 18034, вул. Онопрієнка, 8, https://orcid.org/0000-0001-7868-0155

\section{НАВЧАННЯ ЧИТАННЮ ТЕХНІЧНИХ ТЕКСТІВ ЗА СПЕЦАЛЬНІСТЮ АНГЛІЙСЬКОЮ МОВОЮ ЧЕРЕЗ ОСОБИСТІСНО- ЗОРІЕНТОВАНИЙ ПІДХІД ЯК НЕОБХІДНИЙ ЕЛЕМЕНТ ОВОЛОДІННЯ ІНОЗЕМНОЮ МОВОЮ У ЗВО ТЕХНІЧНОГО СПРЯМУВАННЯ}

Анотація. Наукова розвідка присвячена одному із найвагоміших елементів оволодіння іноземною мовою у закладах вищої освіти технічного спрямування навчанню читанню текстів англійською мовою за спеціальністю 3 використанням особистісно-зорієнтованого підходу.

У статті зосереджена увага на особистості студента як здобувача вищої освіти у ЗВО немовних спеціальностей. Підкреслено важливість та необхідність акцентування уваги на потребах здобувачів вищої освіти ЗВО технічного спрямування оволодівати іноземною мовою крізь призму їхньої майбутньої спеціальності. Показано, що особистісно-зорієнтований підхід - це методологічна орієнтація викладачів ЗВО, яка, спираючись на систему взаємопов'язаних понять, ідей та способів дій, підтримує і забезпечує процеси самопізнання, самовдосконалення та самореалізації особистості здобувача вищої освіти як майбутнього фахівця обраної спеціальності. Важливо усвідомлювати, що найважливішим завданням вищої освіти України $\epsilon$ підготовка випускника - професіонала, упевненого у своїх силах, здатного до 
критичного мислення, інновацій та самоосвіти, до постановки та розв'язання проблем.

Підкреслено зв’язок формування такої мовленнєвої компетентності як читання та розуміння неадаптованих технічних текстів іноземною мовою 3 отриманням професійних знань і навичок. Охарактеризовано здобувача вищої освіти як читача іноземної літератури за спеціальністю. Наведено критерії відбору текстів для читання на заняттях 3 іноземної мови у закладах вищої освіти технічного спрямування. Акцентовано увагу на важливості об'єднання технічних текстів для вивчення на заняттях з іноземної мови у тематичні цикли. Підкреслено необхідність дотримання послідовності та повторюваності лексичного матеріалу у вищезазначених тематичних циклах, так як рецептивне засвоєння лексичних одиниць можливе лише при достатній їх повторюваності в текстах для читання. Пояснено, що лише систематичне читання іншомовної літератури зі спеціальності сприяє накопиченню необхідного словникового запасу. Вивчено, що тематичні, системно-пов'язані цикли професійноорієнтованих технічних текстів для читання іноземною мовою, доцільно супроводжувати словниками, які включають основні поняття та терміни, запам'ятовування яких може полегшити і прискорити процес навчання читанню технічної літератури зі спеціальності.

Ключові слова: професійно-орієнтовані технічні тексти, особистіснозорієнтований підхід, навчання читанню технічних текстів за спеціальністю, оволодіння іноземною мовою, компетентність.

Introduction. The relevance of the study is determined by rethinking the role of the individual in the spiritual life of the society. One of the strategic tasks of reforming education in Ukraine, defined by the State National Program "Education", is the formation of an educated and creative personality. Among the priority areas of the higher education reform, the need to achieve a qualitatively new level in the study of basic academic subjects: Ukrainian and Foreign Languages ones is identified. The ways to reform the content of general education training include the formation of humanitarian thinking, mastering the native, state and foreign languages. In the context of the traditional approach to training specialists in higher education, insufficient attention is paid to teaching a foreign language to students of nonphilological specialties, since for them this discipline is not considered to be a profile one. Moreover, changes in the political and economic situation of our country are ignored, its strategic task is integration into Europe. In such circumstances, personality-oriented teaching of a foreign language to students of non-philological specialties of higher educational institutions becomes of particular importance, since it is aimed at forming the personality of students in the process of mastering a foreign language.

It should be noted that modern higher education is gradually being reoriented to the development of the student's personality. However, this process lacks purposefulness and scientific and methodological support. 
Therefore, the process of "personal" restructuring of the educational process in higher educational institutions occurs spontaneously, slowly, and inefficiently. In this regard, educators are increasingly aware of the urgent need to create and implement a personal approach to the student as one of the principles of organizing educational work in higher education.

This approach should contribute to a more purposeful, harmonious development of the student as a future creative, professionally acting specialist.

Analysis of the recent research. Determining the theoretical and methodological foundations of the personal approach in teaching students, it is advisable to be based on certain scientific provisions on the formation of this approach in psychology and pedagogy; on the results of psychological research of the individual.

Scientific prerequisites for the emergence of the personal approach were gradually determined in the research of personality in its various aspects, which were conducted by such representatives of classical psychology as W. James, Z. Freud, I. O. Sikorskyi, K. Jung, J. Piaget, L. S. Vyhotskyi, S. L. Rubinshtein, B. H. Ananiev, V. H. Kovalov, V. N. Miasyshchev, A. M. Leontiev, V. S. Merlin, A. A. Bodalov and many others.

Modern requirements for the formation of a personal approach were gradually determined in the research of such scientists as K. O. Abulkhanova-Slavska, O. H. Asmolov, I. D. Bekh, M. I. Boryshevskyi, V. V. Davydov, V. O. Molyako, I. S. Yakymanska and others.

In the special field of psychology and pedagogy of labor and professional training, important prerequisites for the formation of a personal approach were developed in the research of A. M. Aleksiuk, H. A. Ball, I. A. Zyazyun, V. A. Kozakov, H. S. Kostyuk, S. D. Maksymenko, N. H. Nychkalo, V. A. Semychenko, O. M. Piekhota, L. P. Pukhovska, V. V. Chebysheva.

In recent years, there has been a significant increase in interest in the personal approach in pedagogical psychology and practical pedagogy. Taking into consideration the complexity of developing such an approach, researchers consider it appropriate to build it on the way to moving to it from other, more developed approaches. Therefore, such forms of it are proposed as "personal-social-activity approach" (A. V. Barabanshchykov and M. F. Fedenko), "principle of activitypersonal approach" (V. I. Andreiev), "personal-activity approach" (I. O. Zymnia), "systematic personal-activity approach" (S. D. Maksymenko) and others.

The personal approach is established as a key psychological and pedagogical principle of organizing the educational process, on which the effectiveness of reorientation of the educational system to the development of students' personality largely depends.

The literature sources analyzed by us on personality development in the field of teaching foreign languages, the socio-pedagogical significance of the problem and its insufficient theoretical and methodological development, the objective need for specialists who speak a foreign language, personal experience of practical work as a 
foreign language educator gave grounds for choosing a research topic: "Teaching to read technical texts in the specialty in English through a personality-oriented approach as a necessary element of mastering a foreign language in technical higher educational institutions".

The purpose of the article is to analyze one of the most important elements of mastering a foreign language in the technical higher educational institutions teaching reading texts in English in the specialty using a personality-oriented approach.

Results. The implementation of professionally-oriented learning to read in a foreign language is possible with the correct selection of the text material in accordance with the stage and main goals of training, taking into account the needs and capabilities of students. In this regard, on the one hand, a comprehensive analysis of the sources of information on the specialty in a foreign language is required, and on the other hand, knowledge of the student's characteristics as a reader of specialized technical literature in a foreign language.

By the characteristics of a student as a reader of foreign specialized literature, we understand:

1) professional knowledge of a student (knowledge of the specialty) and language (knowledge of grammar and vocabulary the language of which is being studied as well as the rules of compositional, semantic-syntactic and stylistic organization of a scientific and technical text);

2) the range of interests and needs of a student and their attitude to learning a foreign language;

3) psychological characteristics of a student age;

4) individual and psychological characteristics of students;

5) the nature of the actual use of knowledge obtained from foreign texts in the student's educational and professional activities;

6) the level of culture of reading scientific and technical literature in a foreign language.

Taking into account these characteristics allows us to select texts for reading in accordance with the professional orientation of students and organize targeted training in reading foreign-language literature in the specialty. Let's take a closer look at each of these characteristics of a student as a reader of specialized technical literature in a foreign language.

When selecting texts for reading, first of all, it is necessary to take into consideration professional knowledge, since the discrepancy between the level of information contained in a foreign-language text and the level of competence of a student in the relevant field of knowledge in their native language will not only interfere with understanding the foreign-language text, but also reduce interest in reading foreign-language literature in the specialty and cause a negative attitude to learning a foreign language in general.

Therefore, first of all, together with educators of specialized departments the most relevant and interesting issues in the specialty for a particular stage of training 
are determined, taking into account which thematic cycles of systemically related educational materials in a foreign language are compiled. Coordination of work with specialized departments allows us to identify the amount of students' knowledge in the specialty in accordance with the stage of training and select texts that correspond to this level of specialized training of a student.

Thus, the joint work of educators of the department of foreign languages and specialized departments contributes to a more correct organization of the entire educational process of training highly qualified specialists in a technical educational institution.

When selecting scientific and technical texts for reading in a foreign language, it is necessary to take into account their compliance with the language competence of students. The text that is offered to the student for reading must correspond to the level of their language skills. In this regard, of course, it is impossible to start learning to read texts with the ones that differ, for example, in the complexity of the content and have a large amount of unfamiliar vocabulary. In order for the technical texts in a foreign language selected for reading to correspond to the student's language capabilities, after a preliminary assessment of the content of the texts, an analysis of their language features is required. As a rule, information in popular scientific professionally-oriented texts unlike articles and abstract journals, monographs and patents is quite simple in vocabulary and syntax, unified terminologically. That is, both the language form and the content of such texts most often correspond to the level of professional and language training of junior students. Therefore, such texts can be used to teach professionally-oriented reading at the initial stage of learning a foreign language in technical higher educational institutions.

Language and professional training of senior students of technical higher educational institutions allows us to use various monographs, patents, articles from special journals, etc. to teach professionally-oriented reading in a foreign language. At the same time, the analysis and selection of professionally-oriented texts for teaching reading specialized foreign literature should take place in accordance with the interests and needs of students. Thematic, systematically organized selection of professionally-oriented texts related to the content of lectures and practical classes in the specialty, purposefully form the student's stable interest in learning a foreign language as a source of new information in the specialty. And this, in turn, helps the student to consider a foreign language as a means of studying the specialty. In addition, the student has a need to learn a foreign language, as this allows them to improve in their specialty and successfully conduct research work, including writing term papers and theses.

Teaching to read on professionally-oriented, systematically organized in thematic cycles text material changes the attitude of the student and their attitude to foreign language classes in general, since learning a foreign language is primarily "determined by the degree of its necessity for activities, especially for real tangible activities in the near future" $[1, \mathrm{p} .7]$.

Thus, the coordination of the problems of technical texts for reading in a foreign language with the content of lectures and practical classes in the specialty as well as 
the organization of the necessary conditions for the real use of information received by students in foreign language specialized literature (e.g. preparation for a scientific and technical conference, work on course or diploma projects) contribute not only to the purposeful formation of a student's positive attitude to this subject, but also to the development of the need to read specialized literature in a foreign language.

The latter factor, in turn, is also valuable because constant reading of professionally-oriented literature is necessary for the creative activity of a specialist in their independent work. In addition to taking into account the professional and language knowledge of the student as well as their interests, needs and attitude to learning a foreign language, when compiling thematic cycles of foreign-language texts, it is necessary to take into consideration the specifics of the psychological characteristics of the student audience. The latter generally contributes to the process of learning to read a foreign-language text.

B. H. Ananiev draws attention to that at the student age in the structure of intelligence there are two leading nuclei: mnemological, which includes memory and thinking, and attentional [2, p. 203].

Thus, the student audience has all the necessary prerequisites for effective learning to read specialized literature in a foreign language. At the same time, when selecting professionally-oriented educational materials in a foreign language, one should not forget about individual psychological characteristics and opportunities, about the personality of students.

Therefore, in foreign language classes, it is necessary to constantly carry out differentiated training based on the individual psychological characteristics of students [3].

A foreign language educator, systematically working with a relatively small student group, has the opportunity to successfully study and predict the capabilities of their students and, in accordance with this, provide for the selection of technical specialized texts of various complexities in a foreign language and various types and forms of work with them. Some students who easily master a foreign language, are interested in research work and have real opportunities for its successful implementation, should be purposefully involved from the very beginning of their studies at a higher educational institution (together with specialized departments) in reading original literature on topical issues of the specialty. From such students, it is necessary then to form specialized training groups of translators of technical literature. Other students should be taught according to the normal academic program.

Thus, it is necessary to proceed from the real capabilities of each student of a student group and set them feasible tasks that correspond to their individual psychological characteristics. At the same time, during the selection and further professionally-oriented training in reading literature in a foreign language, it is necessary to provide for the possibility and forms of real use of information obtained from texts in the nearest educational, professional and research activities of the student and, in accordance with this, conduct a special selection of foreign-language literature. 
Specialized foreign-language literature is used for various purposes. A student can read foreign-language literature in their specialty to select material for a course or thesis, make a report at a conference, conduct an information search on the topic of research work, and so on.

Thus, during the selection and further training in reading technical specialized literature in a foreign language, in addition to the above factors, it is necessary to take into account the level of development of the student's culture of reading scientific and technical literature in a foreign language. By reading culture, we mean the ability to apply an adequate way of reading various types of specialized technical literature in a foreign language in accordance with a specific goal.

Along with other factors, reading culture involves:

1) the ability to conduct an information search on a given problem;

2) the ability to read a technical text correctly in a foreign language;

3 ) the ability to navigate various types of technical text.

In accordance with this, different types of texts should be provided for teaching different types of reading: search, review, introductory and learning $[4$, p. 96]. At the same time, it is necessary to show students different ways of reading the same technical text, depending on the goals.

Reading can be overview if you need to determine what is said in the text, or you need to make a bibliography in a foreign language on a particular issue. Searching for information on a specific problem is the essence of search reading. Reading will be for informational purposes only if specialized literature in a foreign language is read for the purpose of general familiarization with the information of the text. Finally, reading will be learning if readers aim to study in depth the problem addressed in a foreign-language technical text.

Thus, the system of thematically selected professionally-oriented educational materials in a foreign language [5, p. 60], including various types of technical texts, provides for teaching different types of reading and, accordingly, contributes to the development of the student's ability to navigate well in various types of specialized texts in a foreign language and choose the correct reading strategy depending on the purpose of reading.

After analyzing and selecting professionally-oriented texts in a foreign language in accordance with the considered characteristics of the student as a reader of specialized foreign language literature, these texts are combined into thematic cycles. In such systematically organized texts for reading, it is necessary to observe the consistency and repeatability of lexical material.

It is known that receptive assimilation of lexical units is possible only if they are sufficiently repeated in texts for reading. Systematic reading of foreign language literature in the specialty contributes to the accumulation of the necessary vocabulary. As this accumulation occurs, new vocabulary is easier to remember, or it gradually enters the system with previously learned vocabulary based on the word-forming principle and on associations based on similarity and contrast. Thematic, systemrelated cycles of professionally-oriented technical texts for reading in a foreign 
language, it is advisable to accompany dictionaries that include basic concepts and terms memorizing which can facilitate and speed up the process of learning to read technical literature in the specialty.

Conclusions. Thus, a personal approach to professionally-oriented learning to read specialized technical literature in a foreign language involves, along with other factors, educational foreign-language text material that is adequate to both the goals and stage of training as well as the content of lectures and practical classes in the specialty.

In addition, professionally oriented learning to read specialized technical literature in a foreign language requires careful selection of the educational text material itself as well as comprehensive consideration of all the characteristics of the student as a reader of technical literature in a foreign language.

\section{References:}

1. Kabardov, M. K. (1983). Rol individualnykh razlichiy v uspeshnosti ovladeniya inostrannym yazykom (na materiale intensivnogo obucheniya) [The role of individual differences in the success of mastering a foreign language (based on the material of intensive training)]. Extended abstract of candidate's thesis. M. [in Russian].

2. Ananiev, B. H. (1972). K izucheniyu vozrastnykh osobennostey vzroslykh lyudey [To study the age characteristics of adults]. Razvitiye psikhofiziologicheskikh funktsiy vzroslykh lyudey - Development of psychophysiological functions of adults (pp. 180-220). M.: Pedahohika [in Russian].

3. Spirkina, O. O. (2005). Osobystisno-oriientovanyi pidkhid do navchannia slovotvorenniu ta chytanniu u vyshchykh navchalnykh zakladakh MNS Ukrainy [Personality-oriented approach to teaching word formation and reading in higher educational institutions of the Ministry of Emergency Situations of Ukraine]. Zbirnyk naukovykh prats Poltavskoho derzhavnoho pedahohichnoho universytetu imeni V. H. Korolenka - Collection of scientific works of the V. G. Korolenko Poltava State Pedagogical University. (Vypysk 2 (41)). (pp. 181-186). Poltava. [in Ukrainian].

4. Folomkina, S. K. (1987). Obucheniye chteniyu na inostrannom yazyke $v$ neyazykovom vuze [Teaching reading in a foreign language in a non-linguistic university]. M.: Vysschaia shkola [in Russian].

5. Poliakova, T. Yu. (1987) Situativnyy podkhod v professionalno-oriyentirovannom obuchenii chteniyu na starshem etape tekhnicheskogo vuza [Situational approach in professionally-oriented teaching of reading at the senior stage of a technical university]. Professionalnaya oriyentirovannost obucheniya inostrannoти yazyku v usloviyakh neyazykovogo vuza - Professional orientation of foreign language teaching in a non-linguistic university. (Vyp. 302). P. 60) [in Russian].

\section{Лimepamypa:}

1. Кабардов М. К. Роль индивидуальных различий в успешности овладения иностранным языком (на материале интенсивного обучения): Автореф. дис. ... канд. пед. наук. М., 1983. 19 с.

2. Ананьев Б. Г. К изучению возрастных особенностей взрослых людей // Развитие психофизиологических функций взрослых людей. М.: Педагогика, 1972. С. 180-220.

3. Спіркіна О. О. Особистісно-орієнтований підхід до навчання словотворенню та читанню у вищих навчальних закладах МНC України // Збірник наукових праць Полтавського державного педагогічного університету імені В. Г. Короленка. Випуск 2 (41). Полтава, 2005. Серія «Педагогічні науки». С. 181-186.

4. Фоломкина С. К. Обучение чтению на иностранном языке в неязыковом вузе. М.: Высшая школа, 1987. 208 с.

5. Полякова Т. Ю. Ситуативный подход в профессионально-ориентированном обучении чтению на старшем этапе технического вуза // Профессиональная ориентированность обучения иностранному языку в условиях неязыкового вуза / Тр. МГПИИЯ им. М. Тореза, Вып. 302. М., 1987. С. 60. 